\title{
RESEARCH PAPER \\ ASSESSMENT OF THE RESETTLEMENT COMPENSATION SATISFACTION OF WOOD WORKERS AT SOKOBAN, KUMASI
}

\author{
V. K. Quagraine ${ }^{1}$, R. A. Oppong ${ }^{2}$ and K. Twumasi-Ampofo ${ }^{3}$ \\ ${ }^{1 \& 2}$ Department of Architecture, College of Art and Built Environment, \\ KNUST, Kumasi, Ghana \\ ${ }^{3}$ Building and Road Research Institute-CSIR, Kumasi, Ghana
}

\begin{abstract}
Resettlement has been one of the strategies used to pave way for development and redevelopment of infrastructure in major cities of Ghana in the past few decades. Resettlement is usually characterized by displacement of people and their livelihoods. In Kumasi, resettlement has physically displaced over 10,000 people mostly traders, in and around the Central Business District. Kumasi has undergone significant development in the past two decades in the areas of road and housing construction, resulting in the resettlement of some commercial neighborhoods including the wood merchants from Anloga to allow for the construction of the south-eastern section of the ring road from Oforikrom (Anloga) to Nhyiaeso. This study assessed the outcome of involuntary resettlement of wood merchants from Anloga to Sokoban Wood Village in terms of compensation, improvement in working space and the impact on the timber trade. The study used mixed methods: it relied on the administration of questionnaires and interviews to gather data from respondents for analysis as well as the use of dependent sample T-test for hypothesis testing to evaluate the change in livelihood that resulted from the resettlement programme. The study revealed a significant improvement in the livelihood of the displaced workers after the resettlement.
\end{abstract}

Keywords: Resettlement, Infrastructure, Compensation, Satisfaction, Livelihoods

\section{INTRODUCTION}

Resettlement has been one of the strategies used to pave the way for infrastructure development in Ghana. In Kumasi, resettlement has displaced about 10,000 people mostly traders within the Central Business District (CBD). Ghana has an average urban population growth rate of $2.7 \%$ per annum (Ghana Statistical Service [GSS], 2012) which has made urban needs including the provision of commercial facilities, road networks and other infrastructure development a major concern of city authorities. Kumasi is the capital of the Ashanti Region and has a population of about 2,035,064 


\section{Quagraine et al.}

persons (GSS, 2012). The Government of Ghana, in 2005, decided to construct (in $\mathrm{Ku}$ masi) a $3.2 \mathrm{~km}$ road at the south-eastern part of the existing by-pass from Oforikrom to Nhyiaeso, to widen another $2.7 \mathrm{~km}$ stretch of the Lake road and to connect both roads at Asokwa with an interchange (Frimpong, 2008) as shown in Fig. 1 below.

Resettlement of the wood market at Anloga was therefore inevitable since the highway was to pass through the market. The OforikromHyiaeso bypass construction was preceded by the completion of the Sokoban Wood Village project, which was a key component of the road construction project where the timber market at Anloga was resettled. Ghana has embarked on a number of resettlement projects over the years. Most of these resettlement projects were carried out to improve upon the infrastructure. These include resettlement for the construction of three hydroelectric plants namely; the
Akosombo Dam at Akosombo near Atimpoku in the Eastern Region (1964-1968), the Kpong Dam at Kpong near Akuse in the Eastern Region (1978-1981) and the Bui Dam at Bui in the Brong Ahafo Region (2004-2013). These Dam projects led to the displacement of 80,000 people, 6,000 people and 1,200 people respectively (Raschid-Sally et al, 2008). Others include the development of Tema communities as a result of the harbour project (1951-1962), the Keta basin resettlement due to the sea erosion which rendered it a flood risk area (Danquah et $a l, 2014)$ and resettlements due to various mining activities in the country.

Chambers (1969) emphasized that resettlement has two main features, i.e. movement of a population and an element of planning and control. Involuntary resettlement involves direct economic and social losses resulting from displacement caused by acquisition of land or restriction of access to land, together with the

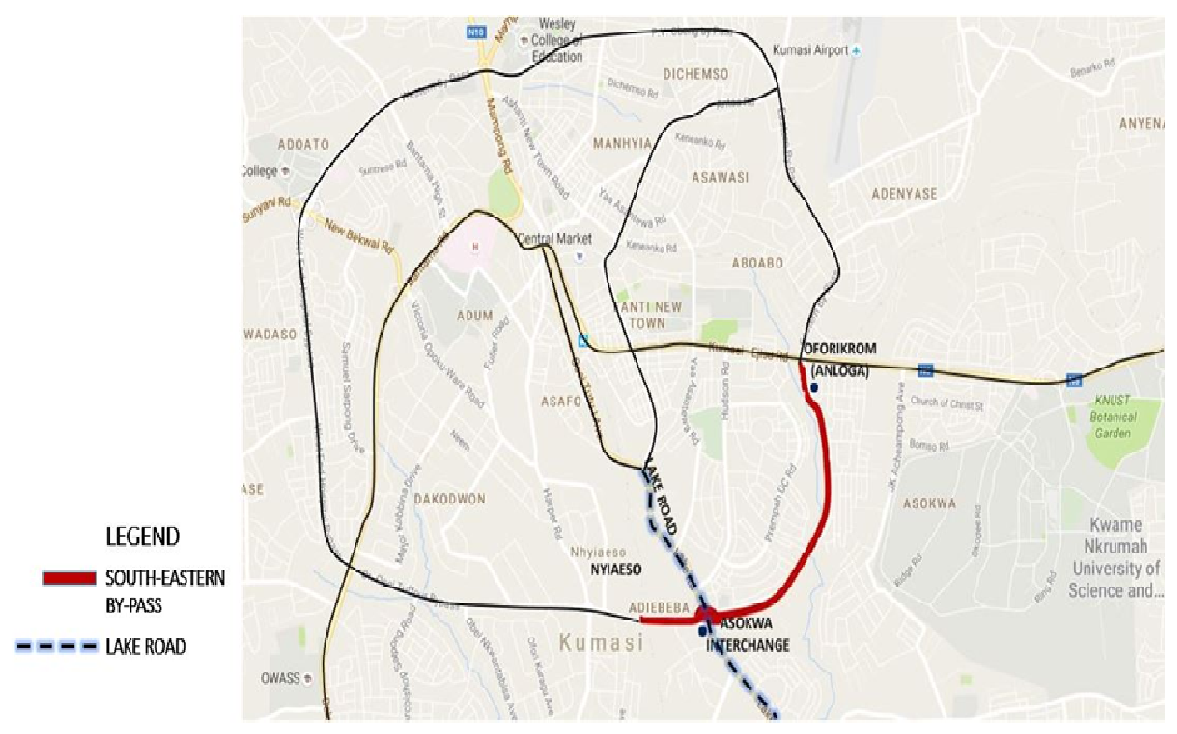

Fig. 1: Map showing South-Eastern by-pass

Source: (Adapted from Google maps, 2016) 
consequent compensatory and remedial measures (Abhas et al, 2010). "It may entail both the physical displacement of people and the disruption of livelihoods" (Murray, 2002), and it is usually referred to as planned resettlement with its accompanied provision of housing, basic services and infrastructure, livelihood opportunities and security of tenure for the displaced households (Van Eerd and Benerjee, 2013).

The Asian Development Bank's (ADB) involuntary resettlement policy includes losses from displacement and the mitigation measures that should be evaluated in resettlement plans to compensate for them (ADB, 1998 and ADB, 2014). The World Bank (2013) makes it clear that involuntary resettlement may cause severe long term hardship, impoverishment and environmental damage, unless appropriate measures are planned and carried out. This involuntary resettlement should be avoided where feasible, or minimized to explore all viable alternative project designs. Where it is not feasible to avoid, resettlement activities are to be conceived and executed as sustainable development programmes, providing sufficient investment resources to enable the persons displaced by the project to share in the projects' benefits. Displaced persons are to be meaningfully consulted and given the opportunity to participate in the planning and implementation of the programme.

Displaced persons are to be assisted in their efforts to improve their livelihoods and standards of living or at least to compensate them, in real terms, to their pre-displacement levels or to the levels prevailing prior to the beginning of project implementation; whichever is higher (World Bank, 2013). Compensation is a critical element in resettlement. It is the provision made to persons whose properties have compulsorily been taken and it is used to reimburse them for property and other associated losses (Asiama, 2015). In the past, it was sufficient for compensation to be considered in terms of monetary values only. Compensation has recently taken a new dimension as national expe- ctations, political realities and international requirements prescribe compensation to cover not only restoration of financial values, but also measures that will contribute to growth, enhance living and working conditions of affected people and address the social factors, such as changes in relationships and cultural values (Kalitsi and Associates, 2008). In Ghana, there are a number of legislative Acts that regulate resettlement processes. There was the Volta River development Act 46. This act prescribed resettlement and compensation as mitigation for the people displaced by the Akosombo and the Kpong Dam Projects (Raschid-Sally et al, 2008). There are other state Legislative Acts including the State Land Act 1962 (Act 125) amended in 2005 (Act 586) and Real Estate and Administration of Lands Act, 1962 (Act 123). Both Act 125 and 586 suggest a lump sum payment to the displaced with emphasis on the degree of social benefits inherent in the land acquisition (Anim-Odame, 2011). It is against these backgrounds of constitutional provision coupled with other legislative acts that the Wood Village was constructed at Sokoban.

\section{STUDY AREA AND METHODS}

\section{The study area}

Sokoban is a suburb of the Kumasi Metropoli$\tan$ Area (KMA). It is located at the southern part of the metropolis. Fig. 2 shows the study areas i.e. Anloga (where the wood market was originally situated) and Sokoban Wood Village (the resettled area). Sokoban before the resettlement in 2008 had a population less than 1,000 whose major occupation was farming, trading and other workers who ply their trade at the CBD of Kumasi. The population of Sokoban has increased to about 1,275 using a growth rate of $2.7 \%$ per annum for the Ashanti Region (Ghana Statistical Service, 2012). However, currently the population during working hours increases to about 6000 to include workers who ply their trade at the wood village.

The Wood Village houses lumbers, carpenters and other woodworkers, with economic activities ranging from the sale of food, wood and 


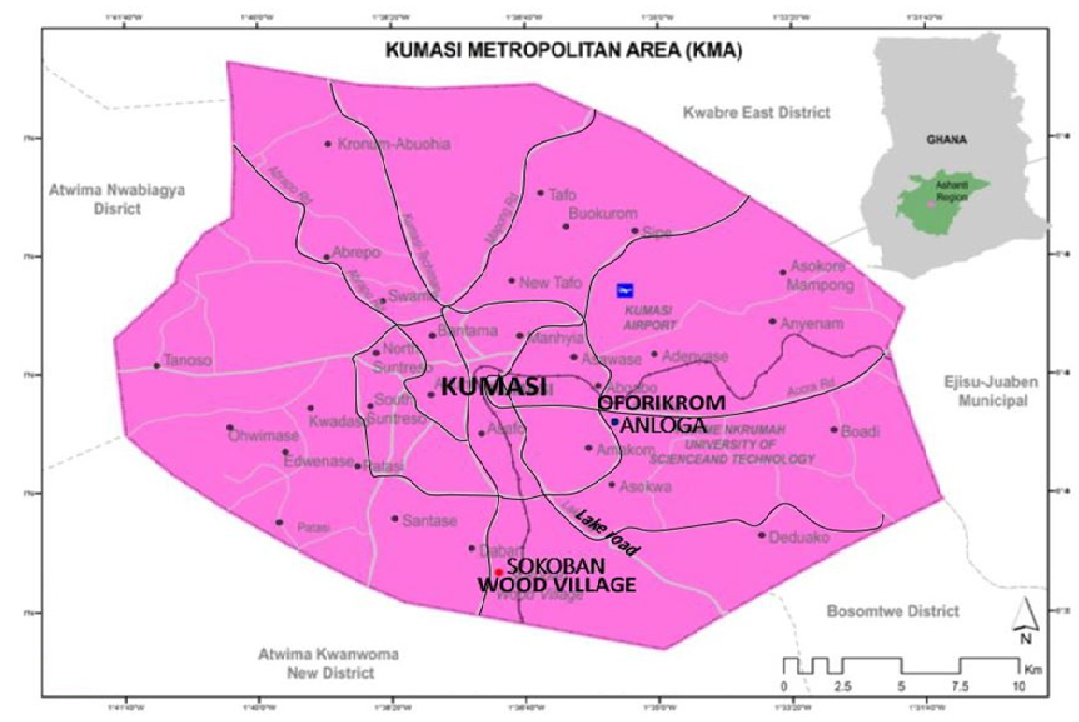

Fig. 2: Map of Kumasi Metropolitan Area showing project location (Source: Adapted from KMA, 2013)

wood products to hardware accessories for wood work. The Wood Village lies east of Sokoban township between longitudes 206500E, 207000E and latitudes 216500N, $216000 \mathrm{~N}$ and it is surrounded by Daban, Kaase, New Apirabo and Asago townships as shown in Fig. 3.

There is a total number of 974 sheds provided by the project at the wood village and the initial allocation was made to accommodate carpenters (C) lumber mills/sellers (LS), hardware sellers (HS), plywood sellers (PS) and saw millers (SM) as shown in Fig. 4. All the sheds in the main facility have eventually been occupied by carpenters due to their numbers, except the sheds for lumber sellers. There are ancillary facilities (AF) including a canteen, a two story administration block which houses a 50 seater capacity conference room, a police post, a health post, financial institutions, a school and sanitary facilities.

The wood village project has attracted several institutions including Abellon (a company that utilizes timber by-products for the production of pallets), financial institutions such as banks and retail outlets to both compliment and take advantage of the resettlement. Figs. 5a and 5b below show a typical carpenter's shed with motorable access ways and vehicle parking area respectively for easy carting of wood to and from the Wood Village.

\section{METHODS}

The mixed method was used for the study. Questionnaires were distributed to a sample size of 250 resettled workers, who are mainly lumber sellers, carpenters and food vendors to collect data about the compensation packages, patronage of goods in the market, waste management as well as the income levels to determine improvement or otherwise on their lives after the resettlement. The resettlement satisfaction levels were also evaluated based on the provision and availability of social amenities in the resettled area. Thirty resettled workers who were members of Anloga Small Scale Carpen- 


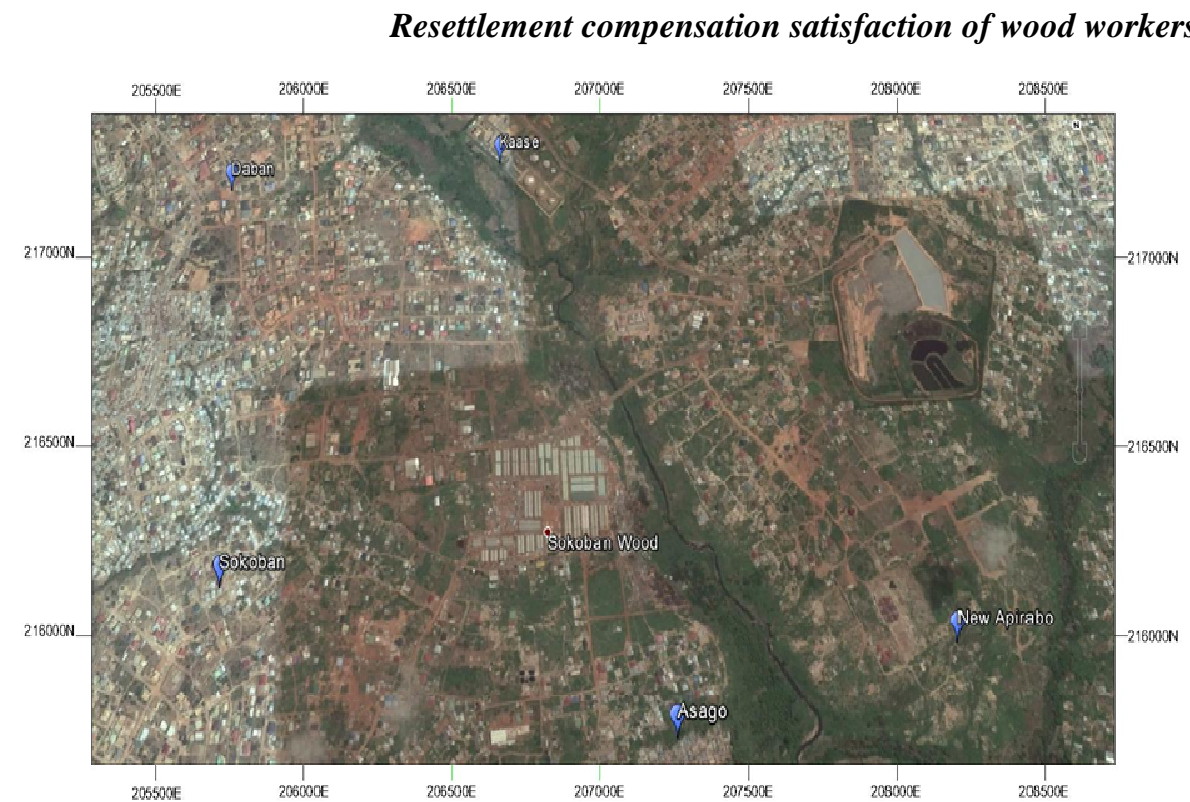

Fig. 3: The Sokoban Wood Village near the Sokobantownship (Source: Adapted from Google Earth, 2016)

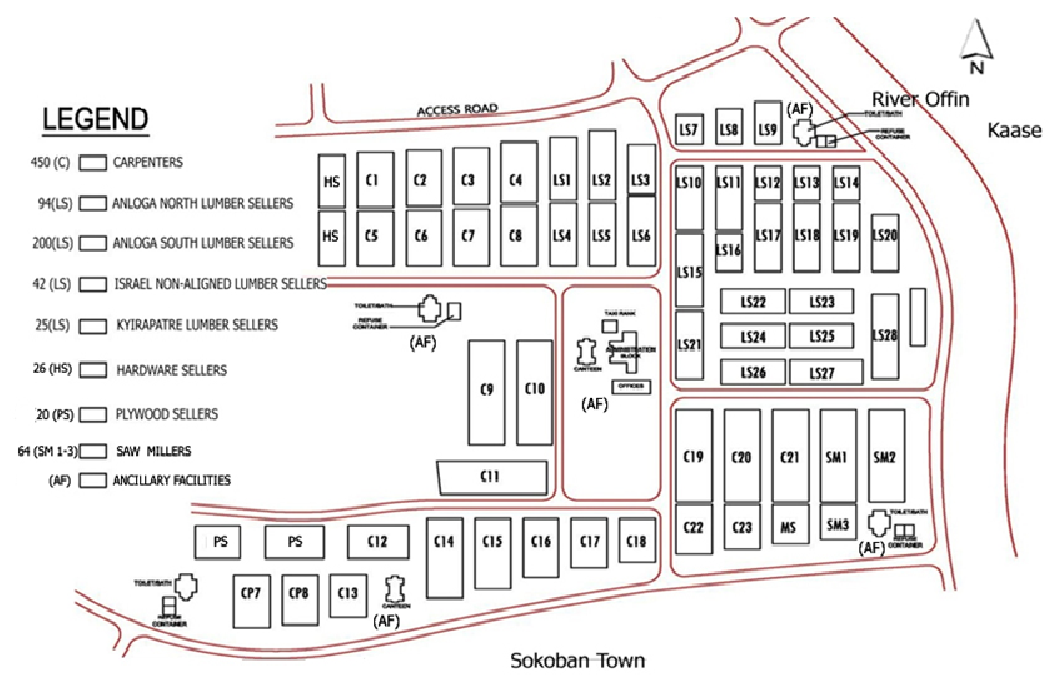

Fig. 4: Block plan of the Sokoban Wood Village (Source: Adopted from ASSCU Plan, 2016) 


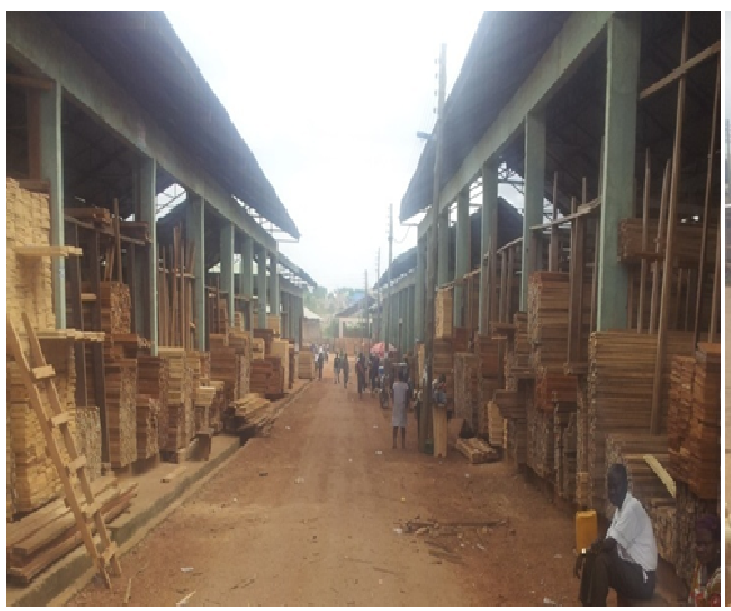

Fig. 5a: Carpenter's shed

ters Union (ASSCU) were also purposively selected and interviewed based on the availability of their daily sales' records before and after the resettlement programme for comparison.

Data was collected on their 2014 and 2015 daily sales at the Sokoban Wood Village for 30 days and was compared to a 30 days daily sales record before the resettlement in 2006 and 2007. The mean daily sales were calculated for both periods. To minimize the influence of inflation the US dollar, a more stable currency was used. Thus, the mean daily sales of both periods 2006/2007 and 2014/2015 were converted to the US dollar using the prevailing rates. For a meaningful comparison between the two different periods, both mean daily sales value were converted into the 2016 worth of the US dollar, using the Federal Reserve Bank of Minneapolis (2006) conversion calculation. These daily sales of the resettled workers were analyzed to verify the change in livelihoods with the aid of dependent sampling T-Test on Statistical Package for Social Scientists (SPSS) for hypothesis testing to confirm the change in livelihood, if any. Secondary data collected from the Kumasi Metropolitan Assembly (KMA), Urban Roads Authority and the

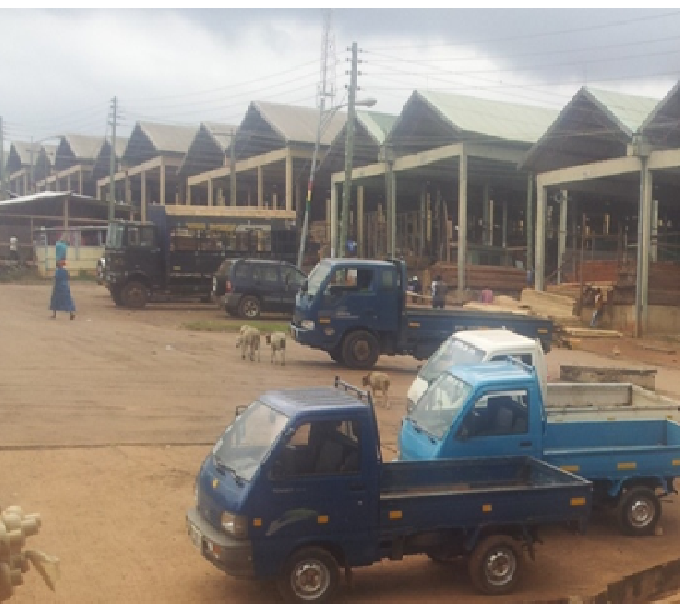

Fig. 5b: Vehicle parking space
ASSCU include the feasibility study reports of the project, land property loss inventory, reports on compensation packages and sales records for in-depth analysis. Physical measurements of the study area were also taken and used to assess improvement in their working environment.

\section{DISCUSSION AND ANALYSIS OF RE- SULTS}

The ASSCU documents revealed that the wood product market in Kumasi located at Oforikrom (Anloga), until the resettlement, had been a source of livelihood for about 5000 people and had evolved from a mini market to a service oriented industry, supplying wood and wood products to a greater part of the country as well as countries within the West African sub-region including Burkina Faso, Mali, Niger and Senegal. The documents from the KMA also revealed examples of losses that were compensated including the land itself, expenses incurred as a direct and reasonable consequence of the acquisition, loss in value to other land owned by the affected owner due to the project, costs of moving and costs of acquiring alternative accommodation as well as costs associated 
Resettlement compensation satisfaction of wood workers ... 106

with reinstallation of wood processing machines.

Out of the 250 respondents who received the questionnaire, 175 responded. This represents $70 \%$ response rate out of which $48.6 \%$ represents lumber sellers, $40 \%$ represents carpenters and $11.4 \%$ represents the minority food vendors. The response as to whether the displaced were consulted before the resettlement project, was affirmative: $84.6 \%$ of the respondents claimed that they were consulted and were fully informed about the resettlement programme. However, only $48 \%$ of the respondents were of the opinion that their views and suggestions, channeled through the leadership of the ASSCU to the implementing agents, have been considered. With regard to the compensation given to the displaced, majority of the respondents $(67.4 \%)$ opined that they were very well compensated for the loss of shop, storage areas, land and houses among others. The compensation package included cash for loss of property, cost of transporting materials and installation of machines. On the other hand, a significant number of respondents (24\%) felt they were not duly compensated.

\section{Resettlement satisfaction}

Table 1 illustrates the opinion of the respondents with regard to the provision and availability of social amenities, services and conditions. $40 \%$ of the respondents opined that travelling distance to work has increased due to the location of their houses and $73.1 \%$ were of the view that the refuse disposal site was inadequate and therefore they were not satisfied. This is supported by a study conducted by Maddens et al (2013) who said that the Sokoban Wood Village faces a major challenge of sawn waste disposal and that about 100-150 metric tons of sawn dust is produced daily culminating in annual sawn dust production of about $75,373 \mathrm{~m}^{3}$ to $95,952 \mathrm{~m}^{3}$ including other waste from the lumber mills and carpenters such as cut-offs and shavings. A significant number of the respondents $(45.1 \%)$ expressed no change in terms of storage space. They still have to store their raw

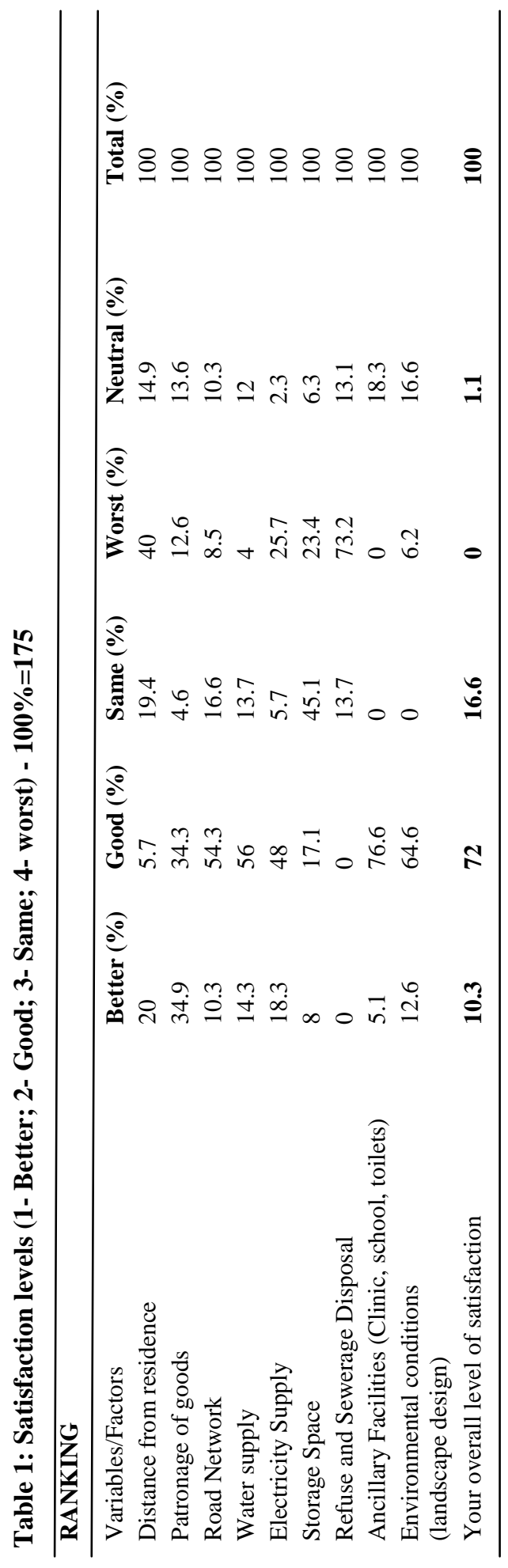

Journal of Science and Technology @ KNUST December 2016 
materials in their production areas whereas $23.4 \%$ claimed to be worse off in terms of storage. Majority of respondents showed satisfaction in the following areas; patronage of goods $(69.2 \%)$, road network $(64.6 \%)$, water supply $(70.3 \%)$, electricity supply $(66.3 \%)$, presence of other facilities such as school, clinic, sanitary facilities and police post $(81.7 \%)$ and $77.2 \%$ for environmental conditions (landscape). This culminates in a high overall level of satisfaction $(82.3 \%)$ among the respondents.

\section{Hypothesis testing}

Following the foregoing section, hypothesis testing was used to evaluate the significance of the satisfaction expressed by respondents with the aid of the SPSS t-test, specifically the dependent sample t-test used to analyze the daily mean sales of the wood workers on record for 30 days before resettlement (2006-2007) and after resettlement (2014-2015).The study hypothesized that:

$\mathrm{H}_{0 \text { : }}$ the livelihood of the workers before the resettlement appears better or same as livelihood after the resettlement $\left(\mathrm{H}_{0:} \mu_{\mathrm{B}} \geq\right.$ $\left.\mu_{\mathrm{A}}\right)$.

$\mathrm{H}_{1}$ : the livelihood of the wood workers before the resettlement appears worse than the livelihood after the resettlement project $\left(\mathrm{H}_{1:} \mu_{\mathrm{B}}<\mu_{\mathrm{A}}\right)$.

Where $\mu_{B}=$ Before Resettlement, $\mu_{A}=$ After Resettlement

$\left(\mathrm{H}_{0}=\right.$ null hypothesis $\mathrm{H}_{1}=$ alternative hypothesis or maintained hypothesis)

The comparison of the 30 days data collected from 30 resettled workers on their mean daily sales with their 30 days mean daily sales on record before the resettlement is shown in Table 2. The calculations are based on the US dollar, a more stable currency, using the Federal Reserve Bank of Minneapolis (2006) conversion for the 2016 worth of the dollar for both 2006-2007 and 2014-2015 periods. The mean sales before the resettlement was converted to the US dollar at the prevailing exchange rate of $\$ 1.00=\mathrm{GH} \phi 1.10$ as at December, 2007 whereas the mean sales after the resettlement was converted to the US dollar at the prevailing exchange rate of $\$ 1.00=\mathrm{GH} \notin 3.80$ as at December, 2015.

Whereas the total daily mean sales before resettlement is $\mathrm{GH} \phi 1,008.00$, the total daily mean sales after the resettlement project amounted $\mathrm{GH} \notin 3,505.00$. However, considering their values in US dollars, a closer difference between 2007-2008 (\$915.90) and 2014-2015(\$921.84) was identified due to depreciation of the cedi over the years. However, the US dollar worth of the total mean sales before resettlement (\$915.90) is equivalent to $\$ 1057.96$ in 2016 worth of the US dollar whereas that of after resettlement (\$921.84) is equivalent to $\$ 931.55$ (Federal Reserve Bank of Minneapolis, 2006). The data (2016 worth of the dollar) obtained was entered into SPSS dependent sample t-test with a confidence level of $95 \%$ and the results are as shown in Table 3 to establish satisfaction levels in livelihood of the wood workers at the Sokoban Wood Village before and after the resettlement project. The computed $\mathrm{t}$ value is 2.633 and is significant at $\mathrm{p}=0.013$ (two tailed) with a degree of freedom of 29 . Since $\mathrm{P}=$ $(0.013 \div 2)=0.0065$ is less than 0.05 , the null hypothesis $\left(\mathrm{H}_{0}\right)$ is rejected and we conclude that livelihood of the wood workers have improved significantly which confirms the high satisfaction levels after the resettlement project.

\section{CONCLUSIONS}

The study unveiled that whereas the resettlement programme substantially reduced the economic activities at Anloga (Oforikrom), it has given way to a more active business life at Sokoban and its environs as well as paving way for improving the road network of the Kumasi Metropolis with the extension of the dual carriage way from Anloga junction to Nhyiaeso. The resettlement has ultimately improved the livelihood of the resettled merchants as well as 
Resettlement compensation satisfaction of wood workers... 108

Table 2: Daily mean sales before and after resettlement

\begin{tabular}{|c|c|c|c|c|c|c|c|}
\hline \multirow[t]{2}{*}{ Days } & \multirow[t]{2}{*}{$\begin{array}{l}\text { ASSCU } \\
\text { Member }\end{array}$} & \multicolumn{2}{|c|}{$\begin{array}{l}\text { Mean daily sales before } \\
\text { resettlement (2006-2007) }\end{array}$} & & \multicolumn{2}{|c|}{$\begin{array}{l}\text { Mean daily sales after } \\
\text { resettlement (2014-2015) }\end{array}$} & \multirow{3}{*}{$\begin{array}{l}\text { Worth (\$) } \\
2016\end{array}$} \\
\hline & & Cedis $(\phi)$ & Dollars (\$) & Worth (\$) & Cedis $(\not)$ & Dollars (\$) & \\
\hline & & & 2007 & 2016 & & 2015 & \\
\hline 1 & 1 & 50.00 & 45.50 & 52.56 & 160.00 & 42.10 & 42.54 \\
\hline 2 & 2 & 15.00 & 13.60 & 15.71 & 70.00 & 18.40 & 18.59 \\
\hline 3 & 3 & 20.00 & 18.10 & 20.91 & 100.00 & 26.30 & 26.58 \\
\hline 4 & 4 & 22.00 & 20.00 & 23.10 & 75.00 & 19.70 & 19.91 \\
\hline 5 & 5 & 25.00 & 22.70 & 26.22 & 90.00 & 23.70 & 23.95 \\
\hline 6 & 6 & 60.00 & 54.50 & 62.95 & 185.00 & 48.70 & 49.21 \\
\hline 7 & 7 & 33.00 & 30.00 & 34.65 & 145.00 & 38.10 & 38.50 \\
\hline 8 & 8 & 24.00 & 21,80 & 25.18 & 120.00 & 31.60 & 31.93 \\
\hline 9 & 9 & 25.00 & 22.70 & 26.22 & 130.00 & 34.20 & 34.56 \\
\hline 10 & 10 & 40.00 & 36.40 & 42.05 & 165.00 & 43.40 & 43.86 \\
\hline 11 & 11 & 22.00 & 20.00 & 23.10 & 75.00 & 19.70 & 19.91 \\
\hline 12 & 12 & 24.00 & 21.80 & 25.18 & 80.00 & 21.00 & 21.22 \\
\hline 13 & 13 & 25.00 & 22.70 & 26.22 & 95.00 & 25.00 & 25.26 \\
\hline 14 & 14 & 35.00 & 31.80 & 36.73 & 105.00 & 27.60 & 27.89 \\
\hline 15 & 15 & 38.00 & 34.50 & 39.85 & 125.00 & 32.90 & 33.25 \\
\hline 16 & 16 & 45.00 & 40.90 & 47.24 & 175.00 & 46.00 & 46.49 \\
\hline 17 & 17 & 20.00 & 18.10 & 20.91 & 60.00 & 15.80 & 15.97 \\
\hline 18 & 18 & 25.00 & 22.70 & 26.22 & 110.00 & 28.90 & 29.20 \\
\hline 19 & 19 & 40.00 & 36.40 & 42.05 & 150.00 & 39.50 & 39.92 \\
\hline 20 & 20 & 30.00 & 27.20 & 31.42 & 165.00 & 43.40 & 43.86 \\
\hline 21 & 21 & 35.00 & 31.80 & 36.73 & 160.00 & 42.10 & 42.54 \\
\hline 22 & 22 & 45.00 & 40.90 & 47.24 & 115.00 & 30.20 & 30.52 \\
\hline 23 & 23 & 35.00 & 31.80 & 36.73 & 120.00 & 31.60 & 31.93 \\
\hline 24 & 24 & 55.00 & 50.00 & 57.76 & 145.00 & 38.10 & 38.50 \\
\hline 25 & 25 & 40.00 & 36.40 & 42.05 & 95.00 & 25.00 & 25.26 \\
\hline 26 & 26 & 35.00 & 31.80 & 36.73 & 100.00 & 26.30 & 26.58 \\
\hline 27 & 27 & 25.00 & 22.70 & 26.22 & 105.00 & 27.60 & 27.89 \\
\hline 28 & 28 & 35.00 & 31.80 & 36.73 & 80.00 & 21.00 & 21.22 \\
\hline 29 & 29 & 40.00 & 36.40 & 42.05 & 95.00 & 25.00 & 25.26 \\
\hline 30 & 30 & 45.00 & 40.90 & 47.24 & 110.00 & 28.94 & 29.25 \\
\hline Total & & $1,008.00$ & 915.90 & 1075.77 & $3,505.00$ & 921.84 & 931.55 \\
\hline
\end{tabular}

Source: Field data, 2016

Table 3: Dependent sample T-Test between sales before and after resettlement

\begin{tabular}{|c|c|c|c|c|c|c|c|c|}
\hline & \multicolumn{5}{|c|}{ Paired Differences } & \multirow[t]{2}{*}{$\mathbf{t}$} & \multirow[t]{2}{*}{ df } & \multirow{2}{*}{$\begin{array}{l}\text { Sig. }(2 \\
\text {-tailed }) \\
\end{array}$} \\
\hline & Mean & $\begin{array}{l}\text { Std. } \\
\text { Deviation }\end{array}$ & $\begin{array}{l}\text { Std. } \\
\text { Error } \\
\text { Mean }\end{array}$ & \multicolumn{2}{|c|}{$\begin{array}{l}95 \% \text { confidence } \\
\text { Interval of the } \\
\text { Difference }\end{array}$} & & & \\
\hline $\begin{array}{l}\text { Pair } 1 \\
\text { Sales_before_resettlement } \\
\text { Sales_after_resettlement }\end{array}$ & 4.21333 & 8.76583 & 1.60041 & $\begin{array}{l}\text { Lower } \\
0.94012\end{array}$ & $\begin{array}{l}\text { Upper } \\
7.48655\end{array}$ & 2.633 & 29 & .013 \\
\hline
\end{tabular}




\section{Quagraine et al.}

artisans in the wood industry. It has improved the road network, water supply, electricity supply, production area (sheds), trucks and car parking lots with loading areas, culminating in increased mean daily sales due to high patronage of goods and services at the Sokoban Village. The study indicates high satisfaction levels with availability of social amenities and improved working conditions for the workers. However, some improvements need to be carried out to further enhance business and consequently the livelihood of re-settlers. There is the need to provide more storage facilities and additional sheds to accommodate new lumber mills and the increasing number of carpenters. Though the challenges of adequate electricity supply is a general national issue, its improvement would guarantee efficient and quality production to meet all delivery times. Wood related companies must be encouraged to set-up at the wood village to reuse the enormous sawn dust (waste) into products such as pallets (briquettes) and particleboards for the local market and export.

\section{REFERENCES}

Abhas, K. J., Barenstein, J. D., Phelps, P. M., Pittet, D. and Sena, S. (2010). Safer Homes, Stronger Communities. A Hand book for Reconstruction after Natural disaster. World Bank Pp. 77-91.

ADB, (1998). Handbook of Resettlement: A Guide to Good Practice. The Asian Development Bank, ISBN 971-152-4.

ADB, (2014). Lose to Gain: Is Involuntary Resettlement a Development Opportunity? Mandaluyong City, Philippines. Edited by Jayantha Perera, Asian Development Bank http://www.adb.org/sites/default/files/ publication/41780/lose-gain-involuntaryresettlement.pdf. Accessed: February, 2016.

Anim-Odame, K. W. (2011). Compulsory acquisition and compensation in Ghana: Principles and Practices, Paper presented at the America Real Estate Society Conference in
Seattle-Washington, USA. 13-16 April, 2011

Asiama, K. O.(2015). Governance in Resettlement from Compulsory Land Acquisition - A Case Study of the Bui Dam Project, Enschede Netherlands. https://www.itc.nl/ library/papers_2015/msc/la/asiama.pdf. Accessed January, 2016.

Angola Small Scale Carpenters (ASSCU), (2016). Plan - 5th Anniversary of the Sokoban Wood illage Brochure

Chambers, R. (1969). Settlement Schemes in Tropical Africa: A study of Organisations and development, Praeger, London.

Danquah, A. J., Attippoe, A. J., Ankrah, S. J., (2014). Assessment of Residential Satisfaction in the Resettlement Towns of the Keta Basi in Ghana. International Journal Civil Engineering, Construction and Estate Management, 2(3) 26- 45.

Federal Reserve Bank of Minneapolis, USA. (2006). What is a dollar worth? CPI Calculat o r I n f o r m a t i o n . h t $\mathrm{t}$ p:// www.minneapolisfed.org/Research/data/us/ calc/index.cfm\#calc. Accessed:29/09/2016

Frimpong, E. D. (2008). Work on Oforikrom Asokwa Starts. www.blogspot.com. Accessed: September, 2015.

Ghana Statistical Service, (2012). 2010 Population and Housing Census, Summary Report of Final Results, Accra.

Google Earth, (2016). Aerial view of Sokoban Wood Village and surrounding township, Accessed on 09/09/2016.

Kalitsi and Associates, (2008). Issues on compensation for Dam Affected Persons. Paper presented at the International Water Management Institute (IWMI) 2nd Ghana Dams Forum. http://ghanadamsdialogue.iwmi.org/ Data/Sites/2/media/projectdocuments/ 
issuepaper compensention.pdf. Accessed: $23 / 08 / 2016$

Kumasi Metropolitan Assembly,(2013). Environmental And Social Management Plan (ESPM) Construction of Access Roads With Kerbs And Drains At Sokoban Wood Village, Kumasi. Draft Report. http://www. lgcsp. mlgrdghanagov. Com/pdf/sakoban \% 20 wood \% 20village_esmp_draft $\% 2$ 0report.pdf. Accessed: October, 2015.

Maddens, J., Snehal, P., Kapila, R. and Pangea, A. (2013). Sokoban Wood Village Project in Kumasi, Ghana. MCI Working Paper Series on Investment in the Millennium Cities $\mathrm{N}^{\circ}$ 13/2013.http://mci.columbia.edu. Accessed: March, 2016.

Muray, G. (2002). Handbook for preparing a Resettlement Plan. International Finance Corporation (IFC). F o r w a r d, h t t p : / / www.ifc.org/wps/wcm/connect/22ad7200488
18/ResettlementHandbook.pdf. Accessed: October, 2015

Raschid-Sally, L., Akoto-Danso, E. K., Kalitsi, E. A. K., Ofori, B. D. and Koranteng, K. T., (2008). The Resettlement Experience of Ghana Analyzed via Case studies of Akosombo and Kpong Dams, 9th Annual Symposium on Property Research in Sri Lanka, Exploring Experiences of Resettlement.

Van-Eerd, M. and Banerjee, B. (2013). Evictions, Acquisition, Expiration and Compensation: Practices and selected Case StudiesUN Habitat Working Paper I. UNON, Publishing Services Section, Nairobi.

World Bank, (2013). Operational Manual: OP 4.2-Involuntary Resettlement (Revised). https://policies.worldbank.org/sites/ppf3/ PPFDocuments/090224b0822f89db.pdf. Accessed: 06//12/ 2015 